\title{
THE RECEPTION OF AVICENNA'S THEORY OF MOTION IN THE TWELFTH CENTURY
}

\author{
ASAD Q. AHMED \\ Department of Near Eastern Studies, University of California, Berkeley 250 \\ Barrows Hall, Berkeley, CA 94720, USA \\ Email: asad.ahmed@berkeley.edu
}

\begin{abstract}
This article explores the reception of Avicenna's theories of motion in the sixth/twelfth century. Avicenna had devised innovative ways of understanding motion in response to various challenges and conditions that the preceding philosophical tradition and his own internal critique had posed. Motion for him was either the state of being between two termini or the traversal of an interval, where the former of these was the extramentally real type and the latter a product of the imagination. In the sixth/twelfth century, the implicit critique of some leading scholars led to the adoption of the thesis in some circles that motion by traversal is extramentally real. This position was accepted as viable both by those who endorsed the atomic and the continuous theory of bodies.
\end{abstract}

Résumé. Cet article se penche sur la réception des théories avicenniennes du mouvement au $\mathrm{VI}^{\mathrm{e}} / \mathrm{XII}^{\mathrm{e}}$ siècle. Avicenne a conçu des façons innovantes de comprendre le mouvement, répondant à la fois aux défis et conditions établis par la tradition philosophique antérieure et à ceux qui naissent de sa critique interne. Le mouvement est pour lui soit le mode d'être entre deux termes, soit le passage ou l'intervalle, le premier étant le type de mouvement extra-mentalement réel, tandis que le second est un produit de l'imagination. $\mathrm{Au} \mathrm{VI}^{\mathrm{e}} / \mathrm{XII}^{\mathrm{e}}$ siècle, la critique implicite conduite par certains savants prééminents aboutit, dans certains cercles, à l'adoption de la thèse selon laquelle le mouvement-passage est extra-mentalement réel. Cette position était jugée viable aussi bien par les tenants de l'atomisme que par ceux de la théorie de la continuité des corps.

\section{INTRODUCTION 1}

In an erudite study published in 2001, Ahmad Hasnawi provided an outline of the theory of motion ${ }^{2}$ developed in the Shif $\vec{a}^{2}$ of Avicenna (d. $1037 \mathrm{CE}$ ). Here he also supplied the historical data from the Greek

${ }^{1}$ I would like to thank Ahmad Hasnawi, Peter Adamson, Jon McGinnis, and the anonymous reviewer for helpful and thought-provoking comments on this paper. The errors that remain are mine.

2 Throughout this article, by motion I mean change in the category of place, quality, and quantity (i.e., kinēsis), though most of the examples the sources consider are limited to change in the category of place. 
commentary tradition, the early Arabic translations of Aristotle's Physics (with accompanying marginalia), and Arabic philosophical engagements that served as the backdrop to Avicenna's innovations. ${ }^{3}$ In a subsequent article, Hasnawi explored further the category in which motion falls for Avicenna; in this case, he not only provided the Graeco-Arabic historical foundations of Avicenna's theory, but also explored its Latin reception. ${ }^{4}$ Following in the footsteps of these articles, Jon McGinnis examined the reception of Avicenna's theory in the forma fluens /fluxus formae debate in the Latin tradition, arguing that the originator of this debate, Albertus Magnus, misunderstood Avicenna's position on the issue, even as he drew his inspiration from him. ${ }^{5}$ Thus, in addition to the analysis of Avicenna's own texts, we have in these three articles some aspects of the evidence of the heritage and legacy of a fundamental contribution of his philosophy. However, we remain uninformed about the reception of Avicenna's theory of motion in the Muslim intellectual tradition. This article begins to fill this gap by means of an examination of discussions in the sixth/twelfth century.

In the first part of this article, I will bring to the fore some of the underlying systematic concerns that motivated Avicenna's theory, followed by a synopsis of our current understanding of his position. Here, the crucial aim will be to lay down the nuts and bolts of Avicenna's edifice - to set the scene - so that we may fully understand the nature of its reception. In the second part, I will examine the critique of this theory as it is found in some sixth/twelfth century philosophical engagements. As examples, I will highlight the works of Abū al-Barakāt al-Baghdādī, Sharaf al-Dīn al-Mas'ūdī, and Fakhr al-Dīn al-Rāzī. ${ }^{6}$

\section{I.A. AVICENNA ON MOTION: SYSTEMATIC CONCERNS}

The theory of motion in Avicenna is developed in view of certain other systematic commitments that are themselves the products of proofs which the Avicennan theory of motion must also satisfy. As we will see in the next section, challenges to the Avicennan theory will appeal

${ }^{3}$ Ahmad Hasnawi, "La définition du mouvement dans la Physique du Šifä d'Avicenne," Arabic Sciences and Philosophy, 11 (2001): 219-55.

${ }^{4}$ Ahmad Hasnawi, "Le statut catégorial du mouvement chez Avicenne: contexte grec et postérité médiévale latine," in Régis Morelon et Ahmad Hasnawi (eds.), De Zénon d'élée à Poincaré, Recueil d'études en hommage à Roshdi Rashed, Les Cahiers du MIDEO 1 (Louvain/Paris, 2004), pp. 607-22.

5 Jon McGinnis, "A medieval Arabic analysis of motion at an instant: The Avicennan sources to the forma fluens/fluxus formae debate," British Journal of the History of Science, 39.2 (2006): $1-17$.

${ }^{6}$ For the reception of Avicenna theories of corporeal form and prime matter among these same figures, see the excellent article by Ayman Shihadeh, "Avicenna's corporeal form and proof of prime matter in twelfth-century critical philosohy: Abū l-Barakāt, al-Mas'ūdī and al-Rāzì," Oriens, 42.3-4 (2014): 363-95. 
both to the substance of these commitments and to the elements of their underlying proofs. Three sets of points stand out as foundational to Avicenna's theory of motion.

\section{Body as Continuity and the Problem of the Space-Between}

In line with the Aristotelian tradition, Avicenna holds that the natural body - the subject of motion - is three-dimensional and is composed of form and matter. ${ }^{7}$ In addition, a body is a continuous unity and can potentially be divided infinitely. ${ }^{8}$ What is interesting for the discussion of motion is that this position about the continuous unity and infinite potential divisibility of bodies is based not on a positive demonstration; rather, it rests squarely on proofs that negate alternative possibilities. These proofs themselves rely on elements that are structurally and systematically important for Avicenna's theory of motion, as will be discussed below.

The two positions that Avicenna is most concerned with refuting are (i) that bodies are composed of an infinite number of actual parts (a position for which Nazzām is known) and (ii) that bodies are composed of a finite number of actual indivisible parts (the famous position of the mutakallimün, henceforth to be designed as the "atomist position" for ease of reference) ${ }^{9}$ Refutations of these alternatives lead Avicenna to his final and positive claim about bodies:

7 On Avicenna's theory of corporeal form and prime matter and its reception in the twelfth century, see Shihadeh, "Avicenna's corporeal form" and Jon McGinnis, Avicenna (New York, 2010), pp. 54ff.

8 See, for example, Avicenna, al-Najāt, ed. Muhammad Dānishpažūh (Tehran, 1364 Sh.), pp. 190-2; id., al-Ishārāt wa-al-tanbīhāt ma'a sharh Nașīr al-Dīn al-Ṭūsī, ed. Sulaymān Dunyā (Cairo, n.d.), vol. 2, pp. 152ff. The discussion of the nature of the body technically falls outside Physics, since the task of a discipline is not to establish the existence or nature of its object, but to explore its essential accidents. The nineteenth century scholar Fadl-i Haqq Khayrābādī notes this point at the beginning of his Hadīya Sa'īdiyya, a late text on Physics, and points out that conventionally this discussion is made part of the Physics because most of the problems in Physics depend on an understanding of the nature of the body. It is perhaps this same observation that led Avicenna to foreground the discussion of the nature of bodies in his later work, the Ishārāt, whereas this same discussion is delayed to Book Three of the Physics of the Shif $\vec{a}$. It is worth noting that, in the Indian context, two works pertaining to the Physics of the Shifā', the Shams Bāzigha of Mahmūd Jawnpūrī (d. 1072/1662) and the Talkhīs al-Shifā of Faḍl-i Imām Khayrābādī (d. 1243 or 44/1827 or 28) both break from the structure of Avicenna's text and also foreground the discussion of the nature of bodies. These decisions may well have been the product of the heavy influence of the Hidāyat al-hikma of al-Abharī, a popular madrasa text, that relies on the Ishärat. See Asad Q. Ahmed and Jon McGinnis, "The Hadīya Sa'idiyya of Faḍl-i Haqq Khayrābādī," in Khaled El-Rouayheb and Sabine Schmidtke (eds.), The Oxford Handbook of Islamic Philosophy (Oxford, forthcoming); Faḍl i-Ḥaqq Khayrābādī, al-Hadìya al-Sa'îdiyya, ed. 'Abd al-Raḥmān (Multān, n.d.), p. 33; Asad Q. Ahmed, "Faḍl-i Imām Khayrābādī," in Kate Fleet et alia (eds.), Encyclopedia of Islam III (Leiden, 2015); Asad Q. Ahmed, "al-Jawnpūrī," in Encyclopedia of Islam III.

9 See Avicenna, The Physics of the Healing, A Parallel English-Arabic Text, translated, introduced, and annotated by Jon McGinnis (Provo, Utah, 2009). Book 3, Chapter 4, is devoted to 
Now, when you expand upon and consider closely what we have presented briefly, you will become absolutely certain of the falsity of this school of thought [i.e., the position of the mutakallimūn]. Also, when this school of thought and its contrary [i.e., the position of Nazzām] are false, the truth must lie in its contradictory opposite - namely, that a single body does not have an actual part but that it is potentially divisible infinitely. ${ }^{10}$

Let me take up three representative proofs reported by Avicenna in the discussion of the nature of bodies in order to pinpoint some outcomes relevant to the theory of motion. First, those who support the atomist position argue that, on the assumption of the validity of Nazzām's notion of bodies, if an object were to traverse (qat') a distance, then it would have to cover an infinite number of actual parts in finite time. This is so because any intermediate terminus (hadd) itself actually consists of further termini, which are themselves actually composed of other such termini and so on. Thus the moving object will never be able to traverse the actual infinite middle (wasat) between two termini. Given this, bodies must be composed of a finite number of indivisible parts. It is as a solution to this challenge, Avicenna reports, that the supporters of the Nazzām position adopted the famous theory of the leap (tafra) - the idea that a moving object does not traverse the middle, but leaps over it to reach the intended terminus. ${ }^{11}$ This proof against the Nazzām position (along with the counterproof) is relevant for our discussion insofar as it highlights that a major concern with establishing the nature of bodies was to satisfy the possibility of traversal (qat ) across a distance. However, this possibility was thwarted because the space-in-between/the middle

the refutation of these alternatives. (Henceforth all references to the Arabic text of the Physics of the Shif $\bar{a}^{3}$ will be from this work [referred to as Avicenna, The Healing]. I have noted where I have modified McGinnis' translation.) The proofs endorsed by the proponents of the alternative positions are supplied in Book 3, Chapter 3; in these cases again, each group arrives at its position by refuting the alternatives. ("Those who said that the body has an infinite number of existing parts... were driven to this account by the impossibility of composing bodies out of indivisible parts and indivisible bodies." [Avicenna, The Healing, p. 279.]) A third more innocuous position is mentioned, but as it claims that bodies are made up of parts that may, in principle, be divided further or that may themselves be bodies with no further parts, Avicenna is not too deeply concerned with refuting it. The more important aspect of this discussion has to do with whether, granted further divisions or the existence of a minimum body that may no longer be divided, the resulting entity would retain its form, e.g., as water, fire, etc. See Avicenna, The Healing, pp. 273-4; 282; Book 3, Chapter 12; Avicenna, al-Najāt, pp. 198ff. A fourth position - that of Shahrastānī - is mentioned and refuted by Khayrābādī, Hadīya, pp. 36f. It asserts that bodies are made up of finite parts that exist in potentiality.

10 Avicenna, The Healing (McGinnis' translation, with a minor stylistic change), p. 301.

11 Avicenna, The Healing, pp. 276, 279; Avicenna, Najāt, pp. 201f. The Nazzām position is reported as that of Epicurus by Avicenna. See 'Abdelhamid Sabra, "Kalām atomism as an alternative philosophy to hellenizing falsafa," in James Montgomery (ed.), Arabic Theology, Arabic Philosophy: From the Many to the One. Essays in Celebration of Richard M. Frank (Louvain, 2006), pp. 199-272. 
(wasat) was actually infinite. Thus any viable theory of motion must overcome the challenge of traversal across the middle. In the case of the atomists, the solution was to posit a finite number of actual indivisible parts, as a finite set of actual parts can in fact be traversed in finite time. One consequence of this theory was that motion was understood as the instantaneous/all-at-once (dufatan) and non-gradual change ${ }^{12}$ (within relevant categories) along discrete units, a position that Avicenna would oppose - among other things - on the grounds of the continuous and unified nature of bodies (see below). ${ }^{13}$

Second (and ironically), the same concerns with the problem of traversal in the space-between loom large in Avicenna's refutation of the atomists. Two of his proofs can illustrate this point. As the language and details are important, I quote them in full. Avicenna writes:

Let us suppose two indivisible atoms (juz'ayn ghayr mutajazzi'ayn), both of which are posited on two indivisible atoms, along with an indivisible atom between the two of them. If this is possible, we say... let us suppose [two of the atoms, one on the top, the other on the bottom,] to move and to collide. So they either meet at the middle atom ( $a l$-juz al-awsat) or they meet at one of the two extremes (ahad al-tarafayn). It is not possible for them to meet at one of the two extremes, because if they meet at one of the two extremes then it would have been that one of them did not move. So they meet at the middle atom. And so the middle [atom] comes to be divided (yașiru al-awsat mutajazzian), because each one of them [i.e., the moving atoms,] had traversed/cut (qataca) some of it. And it was said that it is indivisible. And this is absurd [...]

[Another example is] that it is known that everything has a line of directionality (samt) in relation to another thing, though this be via the intermediary of a third [thing]. [This is the case] of the sun with respect to the terminus (hadd) that is shared between it and the shadow via the intermediary of that of which it is the shadow. For when it moves, its [original] line of directionality passes away and it has a line of directionality in relation to another thing. So when the sun moves an atom $\left(j u z^{\prime}\right)$, it is necessary for its line of directionality to have passed away with respect to that atom. So it is necessary for that in relation to which the sun has a line of directionality to revolve around a small body while being equal to the orbit of the sun. [In this case, the orbit of the sun] is not larger [than it]. [It would also be necessary] for the movement of the shadow to be like the movement of the sun. If that

12 On the question of whether change all at once can occur in the category of quality, see Simplicius, In phys. 234b10-20, 968,1-969,24, pertaining to Aristotle's Physics, VI.4. On the question of gradual vs. change all at once in Avicenna (in the category of substance), see Jon McGinnis, "On the moment of substantial change: a vexed question in the history of ideas," in Jon McGinnis (ed.), Interpreting Avicenna: Science and Philosophy in Medieval Islam (Leiden/Boston, 2004), pp. 42-61.

13 See Avicenna, Najāt, pp. $201 \mathrm{f}$. 
which passes away with the movement of one atom is posited as less than one atom, then it has divided. ${ }^{14}$

Both these proofs rely on the effect actual motion would have on the theory of atomism. In the first case, two atoms, separated by the distance of an atom, begin to move simultaneously and, presumably, at the same velocity. They would thus be expected to encounter each other in the middle-space, which has the distance of an atom, as they traverse the extended medium. Yet if they were to meet in this middle-space, they must share it; and this in turn means that the middle-space, which is the size of an indivisible atom, must itself be divided. Similarly, in the second case, the movement of the sun by the space of one indivisible atom should, in principle, change the line of directionality in relation to the terminus no more than an atom. Yet the sun covers the orbit of a much greater extension, as the relation of its line of directionality to the object continues to shift. Since the movement of the terminus required by the shift covers a much smaller extension than the movement of the sun (after all, the shadow of any object on the earth is still smaller than the orbit of the sun), it would also require that, with each atomic movement of the sun, the terminus move less than an atom. In other words, a middle-space between indivisible atoms is required for this traversal to take place.

Thus, on the assumption that actual motion does take place as a traversal of an extension, it must be granted that, between two termini, no actual indivisible atom can exist - i.e., that motion must occur in the space between the two termini, no matter how small the extension. This, in turn, also means that bodies are continuous and one, i.e., they are not composed of an actual finite number of actual indivisible atoms. Finally, since motion occurs along (or can be imagined as occurring parallel to) bodies, it must also be continuous, like bodies. ${ }^{15}$ To put it differently, the proofs related to the refutation of alternative theories about bodies on the assumption of motion as traversal has led to the consequence that motion must be explained with respect to the space-between (wasat) in a continuum. At this stage then the upshot is that a theory of motion must accommodate traversal across the middle space along a continuous unified extension.

14 Avicenna, Najāt, pp. 199-201. For additional and more extended versions of these proofs, see Avicenna, The Healing, III, 4. Here the translator also supplies useful diagrams to facilitate understanding.

15 Avicenna, Ishārāt, p. 167: "You will also come to learn - on the basis of the state of the possibility that magnitudes [have] for infinite division - that motion that occurs on [these magnitudes] and the time of the motion are likewise [infinitely divisible]. [You will also learn] that neither motion nor time are composed of that which is indivisible." 


\section{The Problem of Motion as a Complete Unity and Stable Extramental Ipseity}

A second underlying consideration in the development of Avicenna's theory of motion is that it exists extramentally as an ipseity, i.e., not as a divested mental universal. This position is a challenge to some followers of Parmenides and Plato who denied both the unity and ipseity (huwīya) of motion on the grounds that nothing of it obtains as a positive reality (mawjūdan hạssilan). For how could something be unified as a this if it exists as two different parts, as the past and the future? Likewise, everything that is unified is complete $(t \bar{a} \mathrm{~mm})$ with respect to its unity and such a unity has a stable existence ( $q \bar{a} r r$ al-wujūd) with its parts being present (hādir al-wujūd). Motion clearly does not have such a stable, unified existence. As a consequence, it is also not an ipseity - a this - with a positive extramental existence. ${ }^{16}$ As we will see below, Avicenna's theory of motion aims to overcome this second set of difficulties.

\section{The Problem of Gradual Transmutation}

Finally, in his analysis, Avicenna must be careful to distinguish motion from generation and corruption. Thus he writes:

Motion is said of the progressive (yasīran yasiran) transmutation (tabaddul) of a stable state in a body. [This happens] by way of an orientation ${ }^{17}$ toward something. Its arrival at [this thing] by means of [motion] is either potential or actual. From this it necessarily [follows] that motion is most certainly a differentiation of a state (mufāraqa li-ḥăl). And it is necessary for this state to be receptive of decrease and increase. For that from which a passing away occurs progressively by way of an orientation toward something, well

16 The terms of the argument are extremely important for the question of the reception of the theory of motion (see, for example, Mas'ū ${ }^{\prime}$ 's statement in the next section). Thus I translate the relevant passage here, using the text supplied by McGinnis. See Avicenna, The Healing, p. 403: "They say, 'How is motion described by ipseity (huwīya), though nothing of it obtains as a positive existence?' And they mention the rest of the doubts that we have already finished with, in what has preceded, in the section on motion and time. [For instance,] they say, 'How can motion be described by unity, though there is no motion except that it is divided into the past and the future and though there is no motion except that it has two times, though those who affirm the unity of time posit as a condition that its time be one? And how can motion be one, though everything that is one is complete $(t \bar{a} m m)$ within that in which it is one, and everything that is complete has a stable existence ( $q \bar{a} r r$ al-wujūd), with parts that are present (hädir al-ajzāa), if it has any? Motion has no stable existence, though it has parts.' See also Hasnawi, "Définition," p. 236. I should point out that, by my translation of qārr al-wujūd as "stable existence," I mean (as I think Avicenna does) an existence that is unchanging in its entirety with respect to any unit of time (even the infinitesimally small). Peter Adamson has suggested the term "integral" for $q \bar{a} r r$ and I think that, in this context, this may prove to be an elegant translation of the term. Private email correspondence, August 1, 2015.

17 Reading without bihi, with Hunt (so indicated by p. 203, n. 5 in Avicenna, Najāt). 
[such a thing] persists for as long as the passing away from it is not finished absolutely [and] completely. Otherwise, the passing away from it would be all at once (duf atan). The state of everything that is like this is either exactly the same [as before] at any time of passing away that is supposed; or it is not exactly the same. However, it is not allowed that it be exactly the same, because if it were exactly the same, then there would be no passing away at all. Thus ${ }^{18}$ everything from which a progressive passing away takes place, when this passing away from it occurs, persists (bāqin), while not having the exact same state with respect to itself. That which is like this is receptive of decrease and increase, such as whiteness and blackness... For this reason, it is said that motion is an actuality and a first perfection (kamāl awwal) for a thing which is in potentiality with respect to the thing $\left(m a^{c} n \bar{a}\right)$ which belongs to it in potentiality. ${ }^{19}$

The emergence of a thing all at once in place of another falls in the category of generation and corruption. It does not qualify as a motion, which is a gradual or progressive emergence of something out of something else. This idea of a gradual emergence then requires two conditions: that a thing persist as itself in some sense and that it also be potentially something else toward which it is directed. This state of affairs requires recourse to the notions of first and second perfections to which Avicenna hints in this passage. ${ }^{20}$ When a thing is at rest, it is potentially oriented toward something else and potentially that other thing. When it begins to move, it is actually directed toward that thing which it is potentially; this is its first perfection. This first perfection is a perfection only with respect to the potentiality toward which it is directed, i.e., the second perfection. This is a crucial element in Avicenna's theory and it requires some reflection. The point Avicenna is making is that this perfection is, in some sense, a potentiality with respect to its own totality. In principle, perfection is a completion of something and, by definition, nothing of its unified totality remains non-actual. The case of motion, however, is different and unique. Avicenna writes:

In this respect, motion shares [something] with the rest of the perfections [i.e., in that it is an actuality]. And it is distinguished from the rest of the perfections with respect to [the fact] that, when the rest of the perfections obtain (hasalat), by virtue of them, the thing [which was in potentiality] comes to be in actuality. There is nothing in it that pertains to this actuality that still is

18 Reading fa-idhan for idh with the rest of the manuscripts. See Avicenna, Najāt, p. 204, n. 2.

19 Avicenna, Najāt, pp. 203-4. See also, Avicenna, The Healing, pp. $107 \mathrm{ff}$.

20 Aristotle had already defined motion as the perfection of that which is in potentiality insofar as it is such. Following him - and his discussion of the soul as the first perfection of a natural body - the commentary tradition modified the definition of motion with notions of first and second perfections. Avicenna's own definition is strikingly similar to those found in the commentaries and in al-Fārābī. See, Hasnawi, "Définition," pp. 224ff. and Ahmad Hasnawi, "Alexandre d'Aphrodise vs. Jean Philopon: notes sur quelques traités d'Alexandre 'perdus' en grec, conservés en arabe,” Arabic Sciences and Philosophy, 4 (1994): 53-109. 
in potentiality. For when that which is black becomes black in actuality, it does not persist (lam yabqa) as potentially black with respect to the totality of the black that it has. And when the square becomes a square in actuality, it does not persist (lam yabqa) as potentially a square with respect to the totality of the square that it has. [However,] the moving thing, when it is moving in actuality, it is thought that it is still moving in potentiality with respect to the totality of the continuous movement whereby it is moving. ${ }^{21}$

Non-instantaneous transformations require that a thing persist in actuality as it is with respect to the totality of its state that is under consideration. Otherwise, the state under consideration will have corrupted and another one will have been generated (and this latter kind of event would not qualify as motion). At the same time, this very actuality of the total state that the thing has is that with respect to which it is potentially in that very state. To put it differently, transformations that do not take place all at once occur in virtue of the total perfection of a state that a thing has, whereby the thing is still potentially in that very state. As noted by Avicenna, such a mode of perfection is distinct from other perfections in that, once these other perfections are achieved in their totality, no part of them, with respect to that very totality, persists as potential. ${ }^{22}$ To sum up, the commitment that motion must be a gradual change has led Avicenna to posit (A) that the totality of the state of motion persists as actual (i.e., it is not corrupted); (B) that the actuality, with respect to its very totality, still persists as a potentiality (i.e., the total and persisting actuality of the state of motion allows for that same state to persist potentially); and (C) that the total actuality be understood as a first perfection.

In summary, the following concerns are foundational drivers of Avicenna's theory of motion. (A) The theory must be able to overcome the aporiae associated with being in the space between any two posited termini and so also on a body that is continuous and one. (B) The theory must account for a phenomenon that is a complete unity and ipseity, with a stable existence ( $q \bar{a} r r$ al-wujūd), and that has an extramental existence. And (C) it must correspond to a notion of gradual and progressive change, which in turn, requires that it be a special kind of first perfection. ${ }^{23}$

21 Avicenna, The Healing, p. 109. The translation I offer above differs from McGinnis' in important respects. My reading appears also to be that of Hasnawi, as suggested by his analysis. See Hasnawi, "Définition,” p. 224. See also, Najāt, p. 193, for a discussion of first and second perfections. A contextualized, developmental, and philosophical analysis of perfection is found in Robert Wisnovsky, Avicenna's Metaphysics in Context (London, 2003), pp. $79 \mathrm{ff}$.

22 See also Hasnawi, "Définition," pp. 223ff.

23 See also Hasnawi, "Définition," esp. pp. 220ff., where a fuller treatment of the elements of Avicenna's theory is presented. I have limited myself to those points that are relevant for the post-Avicennan discussions. 


\section{I.B. AVICENNA'S DEVELOPED THEORY OF MOTION}

With a view to satisfying the aforementioned criteria, two distinct theories of motion are offered by Avicenna. The first theory of motion may be called motion by traversal (haraka qat'iyya). It is the idea that an object can cross or traverse a continuum stretching between two termini. For such a theory to be viable, it must satisfy the three criteria that appeared above. First, it must be grounded in a refutation of atomism; this is a charge that Avicenna had already fulfilled with rigor (based in fact on the assumption of the possibility of traversal). Secondly, traversal must account for the fact of being in the middle; this condition would, in principle, not be a problem over a continuum (though it was clearly a problem for the atomic theory of bodies). Finally, traversal across the middle must be an actual and unified extramental ipseity. It is this challenge that Avicenna is not able to overcome (i.e., within the limits of a theory of motion by traversal).

The problem can be explained as follows. Motion between any two termini cannot exist in extramental reality, because while an object is in the course of crossing the continuum, it has not completed the motion and, just as it arrives at the final terminus, the motion has ceased to exist. To put it differently, in the course of moving, the object has not obtained motion as an actualized and total perfection and, when the totality is achieved by its arrival at the final terminus, the motion has already ended. It is for this reason that Avicenna argues that this kind of motion exists only as imagined or intellected: the eye sees a first terminus at which an object exists and an image of it is preserved in the internal common sense; when the object is seen at the final terminus, the common sense joins the existing image with the current one, thus apprehending the thing as an extension. This extended form is conserved in the image-forming faculty (musawwira), which also individuates the distinct forms as one movement. The latter faulty also continues to carry out a sequential synthesis of the other positions at which an object finds itself with the previous positions. In other words, motion as a traversal is a product of the synthetic activity of the internal faculties; it does not exist extramentally as a continuity. Though this understanding of motion satisfies the concern of crossing a continuum in the space between two termini - a concern that was not satisfied by the atomists - it does not fulfill the requirements that motion must be an extramental ipseity and unity and that, as a consequence, it must be an actual first and total perfection. ${ }^{24}$

This brings us to Avicenna's second sense of motion: it is the state of being intermediate between two termini such that there is no

24 A full analysis, including a discussion of the manner in which the mental images are formed and combined, is found in Hasnawi, "Définition," pp. $228 \mathrm{ff}$. 
supposed terminus where the object exists at the instant before or the instant after. This explanation presumably satisfies all the conditions of motion. For such a state is (1) by definition a being-in-the-middle, so that it is not undermined by the problem of traversal over a divisible middle that is faced by atomists; (2) this state is a persistent extramental ipseity insofar as motion is not conceived as a product of a mental operation that joins being in the first terminus with being in the last terminus; and (3) this state is preserved throughout the continuum as a first perfection even as, insofar as in its total perfection, it is potentially that toward which it tends, i.e., the second perfection. In other words, in virtue of its total first perfection, which is actually tending to the second perfection, it is potentially in the very state of that first perfection. As such then this state allows for the possibility of the gradual emergence of something else. According to Avicenna, this is the proper meaning of motion and he calls it the intermediate state of the moving thing (hâla mutawassita). ${ }^{25}$

\section{POST-AVICENNAN CRITIQUES}

The most pointed and influential twelfth century critique of Avicenna's theories of motion comes from Fakhr al-Dīn al-Rāzī, whose position seems to have developed in view of certain hints in Sharaf al-Dīn al-Mas'ū d̄ and Abū al-Barakāt al-Baghdādī. ${ }^{26}$ This section will examine these positions in the order of complexity. ${ }^{27}$

\section{Sharaf al-Dīn al-Mas' $\bar{u} d \bar{\imath}^{28}$}

The passage from al-Mas'ūdī's commentary on the Ishārāt of Avicenna that seems to have had an influence on the reception of

25 Hasnawi, "Définition,” pp. 232ff.; Avicenna, The Healing, vol. 1, p. 113. The two types of motion are termed haraka qațiyya and haraka tawassuțyya respectively in the post-Avicennan literature. See Jamāl al-Dīn Hillī̄, al-Asrār al-khafiyya fī al-‘ulūm al-'aqliyya, ed. Ḥusām al-Ālūsī and Șāliḥ al-Hāshim (Beirut, 2005), pp. 154ff., for critiques of both positions. The author himself is explicit that motion in the middle is the correct view, though following the critiques, he does not offer any defense of his position. See also Qāḍ̄ Mīr Ḥusayn al-Maybudī, Sharh Hidāyat al-hịkma (Multān, n.d.), pp. 51-3 and Khayrābādī, Hadīya, pp. 91-3. McGinnis, Avicenna, pp. 59ff.

26 For an important contribution to the study of sixth/twelfth century philosophy, especially on al-Mas'ūdī and his reception of al-Baghdādī, see Ayman Shihadeh, "From al-Ghazālī to al-Rāzī: $6^{\text {th }} / 12^{\text {th }}$ century developments in Muslim philosophical theology," Arabic Sciences and Philosophy, 15 (2005): 141-79.

27 Though I present al-Mas'ū ūi first, it is in fact al-Baghdādī's handling of motion that undergirds the former's theory. Mas'ūdī's emphasis on the sequential renewal of parts of motion is also present in al-Rāzì. The two contemporaries knew each other's works well. See Shihadeh, "Avicenna's corporeal form," p. 365; Shihadeh, "From al-Ghazālī," pp. 157ff.

28 I am grateful to Ayman Shihadeh for kindly sharing relevant passages of al-Mas'ūdī's al-Mabahith prior to the publication of the monograph. The text may be found now in 
the latter's theory of motion has to do with the question of the cause of the generation and persistence of a contingent entity. Avicenna had declared in the Ishārāt that that which is contingent in itself does not come to be existent through itself and that, whenever its existence or non-existence becomes preponderant, it is so due to the presence or absence of something else. To this position, al-Mas' $\bar{u} d \overline{1}$ responds:

I say: If he intends by this the beginning of existence, then there is no argument about this ( $f a-l \bar{a}$ kalāma fìhi), since that which is generated must have an agent cause after it has not been [existent]. If, [however,] he intends

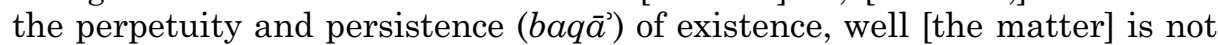
like this absolutely; rather a detailed [consideration] must be [supplied] about this [issue]. For among accidents, there are those that do not have a

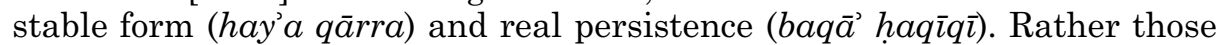
things which are like them renew sequentially (tatajaddadu amthāluhu 'alā $a l-t a^{`} \bar{\alpha} q u b$ ). So [these types] are said to persist figuratively (majāzan). For this persistence needs a cause that makes [it] persist ('illa mubqiya). And this is like motion. For just as the beginning of its existence - I mean its generation - needs an agent cause for it, [likewise,] its persistence and perpetuity also need that cause. [This is so] because its persistence is an expression [referring] to the renewal of those [things] that are like it. ${ }^{29}$ Some mutakallimün think that all accidents are like this [...]. ${ }^{30}$

Al-Mas ūdī's position on motion is not conspicuously directed against Avicenna; indeed, as I will mention below, it sounds too much like certain passages in the Avicennan corpus. Nevertheless, it brings into sharp relief one of the problems associated with the aforementioned second condition that a theory of motion must satisfy. ${ }^{31}$ To recall, the condition is that, for motion to be an extramental ipseity, it must be complete $(t \bar{a} m m)$ and unified and that it must have a stable existence (qārr al-wujūd), with the parts all being present (hâadir al-ajzā). Al-Mas'ūdī conceives of motion as the mutakallimūn do of other accidents: it does not have a stable form or a real persistence and those things that are like each part of the motion (amthāluhu) constantly and sequentially renew due to a cause, in the same manner that a cause is required to generate the

Ayman Shihadeh, Doubts on Avicenna: A Study and Edition of Sharaf al-Dīn al-Mas'üdī’s Commentary on the Ishārāt (Leiden, 2015), pp. 262ff.

29 The other types of accidents that require such a cause of persistence are those that are contrary to what the natural state of the subject demands (for example, the upward motion of earth, whose natural motion is downward). This is the haraka qasriyya (forced motion). Mas' ùdī points out that some mutakallimūn think that all accidents require such a cause of persistence, though this is false. Shihadeh, Doubts, pp. $263 \mathrm{f}$.

${ }^{30}$ Shihadeh, Doubts, p. 262.

31 One reason that he does not expend efforts at highlighting the differences in the theories is that his concern in this passage is not motion, but the question of whether the cause of persistence is required by a contingent entity, in addition to an agent cause of generation. 
first part of the motion. As such, the persistence of motion is only a figurative, non-real idea.

The source of al-Mas'ūdī's inspiration must be Book II, Chapter 12 of the Physics of the Shifa $\vec{a}$ of Avicenna. In the passage in question, Avicenna is concerned with the issue of whether, in the case of a changing object in the flow of time, the posited instant (where the change presumably takes place) should be described with the prior or the posterior quality of the object. The conundrum that is relevant to our discussion is that time is continuous and potentially divisible infinitely, so that anything that is not stable with respect to its states at every instant cannot, by definition, have an instant where the state in the prior instant is the same in the next instant, including the posited instant that divides with respect to past and future states. This is "like motion," writes Avicenna, "for its state does not remain the same at some instant or other, but, rather, at every instant there is a renewal of a new proximity and remoteness, both of which are among the states of motion." ${ }^{2}$ As I noted earlier, Avicenna recognizes the sum of these changing states as motion by traversal, which, taken in its totality, is existent only as the product of mental operations. On the other hand, there is something stable to motion that lends it its definability, viz., the state of being in the middle. Al-Mas 'ùdi seems to be taking the fact of the sequentially renewing states, i.e., the former feature of motion, as the relevant aspect of its definition.

Now I suspect that we may be able to read al-Mas' ūdī as being in agreement with Avicenna, though his approach to the problem and its articulation may have had some repercussions against the Avicennan theory. Let us say that, for al-Mas ${ }^{\mathrm{u}} \mathrm{d} \overline{\mathrm{i}}$, the cause of the constantly - and sequentially - renewing motion is the state of being in the middle that Avicenna considers to be the real sense of motion. As such then al-Mas'ū ${ }^{\prime} \overline{1}$ is not countering Avicenna in saying that this motion, i.e., that which is the product of the renewal, is only figurative; for this would be Avicenna's motion by traversal, which is the product of mere mental operation. However, innocuous though it may have been, al-Mas'ùdī has shifted the conversation about the persistence $(b a q \bar{a})$ of motion away from the theory that Avicenna endorses and within which the question of persistence actually belongs. We might recall that, for Avicenna, motion does have a stable ( $q \bar{a} r r)$, unified (wāhid), and persistent (bāqin) extramental existence, but only as a being-in-the-middle. These same attributes apply to

32 Avicenna, The Healing, p. 242 (emphasis mine). I have modified McGinnis' translation slightly where he translates, "[...] both of which result from the motion." (fa-innahā la tatashābahu hāluhā fī ānin min al-ānāt bal yakūnu fī kulli ānin tajaddudu qurbin wa-bu'din jadīdin humā min ahwāl al-ḥaraka). "[Motion] has been defined in various

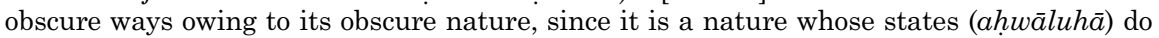
not exist as actually enduring [...]" Avicenna, The Healing, p. 111. 
motion by traversal, but only as a mental synthesis, not as an extramental reality. For al-Mas'ū ${ }^{\prime} \overline{1}$, motion does not have a stable, persistent existence (though perhaps its cause might). But motion is precisely this constantly renewing thing, which is said to persist figuratively. In other words, whatever al-Mas'ùdī may have thought about the underlying cause of motion, the point of discussion has become motion by traversal, not as a mental product, but as an actual renewal of successive and similar states; none of these states, however, has real persistence. What is more, the angle of engagement concerns the cause of the generation and persistence of motion, very much as the mutakallimūn engage the matter with respect to other accidents. ${ }^{33}$

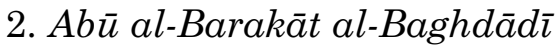

Al-Baghdādì's engagement with the theory of motion is also concerned with traversal and may well have undergirded Mas'ūdì's approach. However, unlike Mas'ū $\overline{\mathrm{l}}$, who agrees with Avicenna in taking

${ }^{33}$ It is important to emphasize that al-Mas ${ }^{`} \bar{u}$ dì is not endorsing a general atomist scheme for the ontology of accidents and that the issue of the sequential generation of motion is not reducible to an atomist notion of space and time. The instability of motion and the consequent idea that it must be renewed is related instead to his position on whether a cause of persistence is required for accidents in general; as an accident, motion falls in a different class in requiring such a cause of persistence. It is in this fact that it is like the accidents of the mutakallimūn. Perhaps al-Mas'ūdī's position can be clarified further with reference to the other type of accident that requires a cause of persistence and his understanding of how such an accident is corrupted. He writes: "Likewise, among accidents is that whose existence is forced (qasriyyan) - against that which the state of its subject requires - by means of a forcing cause that necessitates its existence, despite that which is contrary to it and nullifies it. The persistence of this also needs the persistence of this forcing cause... However, when the forced existent remains in its substrate and is situated [in it] and [when] its necessitating cause, which subdues the nature (al-qāsira li-al-tabía) [of the substrate] which is contrary to it - [when this cause] is strong, then [this forced existent] may persist for some time after the non-existence of its cause. [This is the case] until the original nature becomes strong and repels it and causes it to be non-existent. This is like the heat which is generated in water that is heated by fire. For [this heat] is forced and is contrary to what the nature of water requires... then this heat remains for some time $(s \bar{a} \bar{a} t)$ after the fire has been extinguished and has gone out of existence, since the nature of water is not strong enough to cause it to go out of existence instantaneously (dufatan wāhidatan). It only causes it to go out of existence gradually and little by little ('alā al-tadrīj shay'an fa-shay'an)." (Shihadeh, Doubts, pp. 262-3.)

Accidents that are forced against the nature of their substrates do not require a cause in order to persist for some time. However, they do require a cause of persistence - with the same and stable intensity - in order to exist in perpetuity. The reason for this requirement appears to be the contrary nature that will eventually overcome the forced accident and return the substrate to its natural state. However, as noted above, the constant regeneration that would sustain the forced accident in one and the same stable state does not lead al-Mas' ūdī to adopt an atomist physical ontology, as he is explicit that the return to the natural state is gradual, a possibility that is allowed only in a non-atomist scheme. Motion may perhaps be seen in a similar light in that it is a kind of forced accident that can only have persistence if it is constantly and sequentially renewed. 
traverse motion as a mere figurative construct, al-Baghdādī argues for its extramental reality. First, that motion exists is an obvious and sensed fact:

Minds believe in a primary manner (bidāyat al-adhhān ta'taqidu) in the existence of motion by means of the testimony of the sense and consider it to be a meaning contrary to rest. There is nobody among us who, when he finds a thing in a place at one time and then finds it in another place at another time, does not say about it that it is moving and that it has moved. ${ }^{34}$

This primary testimony of the mind is brought to the fore as a response to the various ways of understanding motion that produce the possibility that motion may be no different from rest or that it may not exist. For example, if motion is the passing away of the fact of touching ${ }^{35}$ a given point, then it is a non-existence, i.e., it is not something with existential import ( $\left.m a^{c} n \bar{a}{ }^{\prime} a d a m \bar{\imath}\right)$. Similarly, if the passing away of this fact of touching a point is itself taken to exist, i.e., insofar as it is the fact of touching another point, then it is not different from rest. If motion is taken to be the combination of the fact of touching the first and second points and the passing away of the fact of touching the first in touching the second point in its place, then motion would still not be a positively existent thing (mawjūd hasșil). This is so because a thing does not obtain positively along with its passing away:

The fact of the touching of the first point, along with its passing away, is [itself simply] non-existent; the passing away does not have existential import in itself; and the fact of the second touching that obtains positively is a rest $[\ldots] .^{36}$

These remarks are reminiscent of Avicenna's discussion of traverse motion that was noted above.

The argument that allows al-Baghdādi to navigate this thorny set of problems and to posit the reality of traverse motion is innovative and nuanced. He writes:

As for how the mind is saved from these difficulties and [is delivered to] the knowledge of the truth and believes it without being harassed by that which is contradictory, well [it is as follows]. We know that we pass judgment about things with respect to an attribute or attributes that we know of them, not insofar as this attribute exists for them or only [insofar] as these attributes

${ }^{34}$ Abū al-Barakāt al-Baghdādī, Kitāb al-Mu'tabar fī al-ḥikma (Hyderabad, 1358 AH), vol. 2, p. 31.

35 I translate mumāssa as "touching" to emphasize it as a verbal noun, as this reading will be important for understanding al-Baghdādī's and al-Rāzì's claims. Alternatively, one might adopt "the fact of being contiguous". In this context, "contiguity" does not carry the intended sense.

${ }^{36}$ Al-Baghdādī, Kitāb al-Mu'tabar, vol. 2, pp. 30-1. 
are gathered together then, so that they are judged of them [only with a view to this existence and this time of judgment]. Rather, [we pass this judgment] insofar as we know these [things] by [these attributes] either then or before or after. As for [judging] insofar as the [attributes] are gathered together or are dispersed, well, they are gathered in the mind and in the soul when we judge. ${ }^{37}$

Thus far, al-Baghdādī has emphasized the important point that, in passing judgment that an attribute or a set of attributes belongs to a thing, neither the actual existence of the thing at the time of judgment nor the collection of the attributes together is a prerequisite for the truth of the proposition. In other words, the temporal range of the act of judgment is not necessarily coterminous with the event; nor are the attributes of the object under consideration necessarily coterminous with each other. He then continues in the manner of Avicenna, though with significant departures:

For when we find a body touching another body, the fact of its touching it is established in our minds and [the fact of its touching] obtains for us as something considered by the faculty of memory (dhikr), especially whenever the period of its being like this is recent. Then when we find it [in] another [state of] touching another body, the first [state of] touching is removed from our minds due to the second [state of] touching. And so we negate [the first state] in a manner that resembles the fact of passing away in existence ( $a l-z a w \bar{a} l$ fi $a l-w u j \bar{u} d)$. So the sense of the fact of passing away - and it is the negation of the first fact of touching - is added to the first fact of touching; then the second fact of touching [is added] to these two [i.e., to the fact of the passing away and the first act of touching]. One of these two is a meaning with a non-existential import ( $\left.m a^{\prime} n \bar{a}{ }^{c} a d a m \bar{\imath}\right)$ and that has no existence in individuated essences, I mean the fact of passing away; the other meaning is non-existent [now], I mean the first fact of touching. Only the third meaning is existent [now] and it is the fact of the third touching. All of these obtain positively in the mind, though some of them in themselves do not obtain positively in individual essences then. We do not judge regarding their existence then, but regarding their existence in an absolute sense. [It is] within the ambit of [this absolute existence] that [its existence] occurs gradually (yatadarraju) either then or before or after. We say about the totality of this that it is existent, i.e., that it has existence, since there is nothing in it which is not deserving of being said to [have] existence. [But this existence] is not all together and not then because the fact of the first and second touching certainly have existence - but not together - but the fact of passing away from the first fact of touching is a mental judgment, by means of a consideration that has existential import (bi-i tiba ar wujū $\bar{\imath})$, regarding something conceived that has no existential import ( $f \bar{\imath}$ mutașawwar 'adam $\bar{\imath}) .{ }^{38}$ So this

37 Al-Baghdādī, Kitā̄b al-Mu'tabar, vol. 2, p. 31.

38 This is the assertion about the non-being of something that has passed away: "The first act of touching is no longer existent". 
is a prior fact of obtaining. Everything from among those [things] that constitute motion undoubtedly has existence, though this be non-stable (ghayr $q \bar{a} r r)$ and [though it may] not be joined to the existence of another constitutive thing. It is not the case that a thing does not have existence, though it not have a stable existence as one [thing]. And when there is nothing among those things that constitute it except that which has existence in some way, then the totality [also] has existence, even though it is not joined together. The totality is not something other than those things that constitute it. ${ }^{39}$

With this detailed argument, al-Baghdādī has tried to establish that motion as a non-stable and non-unified category, i.e., as traversal, still has existence outside of the mind. His argument begins in a fashion very similar to Avicenna's in that he points out the temporally sequential order of our experience of motion: we observe an item at point $x$, then at point $y$, and these two observations underlie the sense of traversal. However, for Avicenna, it appears that the occurrences at the first and last points produce a sense of extended motion by the aid of the internal faculties of common sense (hiss mustarak) and imagination $(k h a y \bar{a} l)$. To reiterate the position I mentioned earlier, the two events do not occur simultaneously; however, if the form of the first occurrence persists in the internal faculty even as the last occurrence presents itself to the external sense, then the two are grasped simultaneously and the imagination records the two temporally-distinct forms as unified. Thus for Avicenna, motion by traversal is non-existent extramentally; it is a continuous reality that is merely intellected or is in the imagination. ${ }^{40}$

The crucial difference between Avicenna and al-Baghdādī is that, for the latter, in addition to the images that occur for the senses at the first and last termini of a motion, the very notions of passing away and coming to be are also derived from the experience. In other words, the mind is certainly an operative and synthesizing factor, but it does not produce the sense of extension/traversal of an object by putting together two disparate images and states, thus rendering motion by traversal a merely mental phenomenon. Rather, it considers together the first and last termini at which an object finds itself, along with the given fact of the passing away of the object from one terminus to the next. Put differently, it merely considers in unison states and forms each one of which is existent extramentally. Each of these elements is constitutive of motion as traversal, though they do not all occur at the same time. The fact that the mind does consider them together at a given time does not render their absolute existence as a merely mental phenomenon, since if all the elements, including

39 Al-Baghdādī, Kitāa al-Mu'tabar, vol. 2, pp. 31-2.
40 Hasnawi, "Définition," pp. 229ff. 
the fact of passing away and coming to be, are real, so is the collection of which these elements are constitutive (i.e., motion by traversal). It is perhaps for this reason that al-Baghdādī refers the process of such consideration neither to the imaginative faculty (musawwira/khaya $\bar{l}$ ) nor to the common sense in which the forms are first imprinted (as done by Avicenna). Instead, in his analysis, he deploys the faculty of memory (dhikr), in relation to which the non-image-bearing notions, which are extracted from actual images, are considered by the soul. ${ }^{41}$ For the notion of the passing away of some specific thing (a judgment of existential import about the non-existentiality of that which has passed away) or the notion of something touching something are not themselves images, but they are invested in extramental images from which they are extracted. It is the consideration of these notions $\left(m a^{c} \bar{a} n \bar{l}\right)$ that makes the mind aware of motion as traversal. ${ }^{42}$ The upshot is that, though motion as traversal is nonstable and non-unified, it does have extramental existence. This position is a challenge both to Avicenna's idea that motion by traversal is extramentally non-existent and to the condition that motion must be stable and unified in order to exist as an ipseity. This makes sense of course, since, as noted above, it is precisely because of the challenge of presenting traverse motion as a stable and unified extramental ipseity that Avicenna developed his innovative theory of motion in the middle.

\section{Fakhr al-Dīn al-Rāzī}

With al-Baghdādī and al-Mas'ūdī, motion by traversal had assumed center stage. Against Avicenna and despite the challenge of some of the conditions that had motivated his innovative perspectives on motion in the middle, both of the later philosophers had defined

41 "As for the imaginative faculty, well it preserves the form (șurra) [of what the senses deliver]. As for the faculty of memory (dhikr), well it preserves the notion (ma'nā) that is taken along with it [i.e., the sensible]. When the sensing [of something] repeats, it becomes memory and when memory repeats, it becomes an experience (tajriba)". See Najāt, p. 169. Al-Baghdādī's psychology is considerably different from that of Avicenna, for example, in the idea that the internal senses for the former are the loci of relation for the experience of a particular input, not the actual place where the form or notion is preserved (that locus is the soul). Nevertheless, the point that the soul is not constructing the experience of extension, but recalling it, is not compromised; in fact it is strengthened insofar as all the elements of the experience are derived from an extramental existence and are located in a unified soul. See Baghdādī, pp. 350ff., esp. 353-4. See also Shlomo Pines, "Abū l-Barakāt," in Peri Bearman et alia (eds.), Encyclopedia of Islam, Second Edition (Brill Online, 2015) (accessed June 16, 2015).

42 It is worth noting that al-Baghdādī consistently uses the expression màna and verbal nouns, such as mumāssa and zawāl in the course of this discussion. Avicenna, by contrast, uses the expression șūra. Avicenna, The Healing, vol. 1, p. 112; Hasnawi, "Définition," p. 231. 
motion as a non-stable, non-unified, and non-persistent thing. AlMas 'ùdī had posited that, since motion must be constantly renewed a consequence of taking it in the sense of traversal - its persistence can only be true figuratively. With this claim, by his own admission, the theory of motion coincided with the kalām theory of accidents in general, but this neither meant an espousal of atomism nor the concession that motion itself was unreal. ${ }^{43}$ In a similar vein, al-Baghdādī posited that motion by traversal is an extramental reality, not a mere mental product, because all its constitutive elements are extramentally real. All the notions associated with motion are extracted from extramental forms and these are preserved by the soul; they are then recalled for consideration by the soul in its association with the faculty of memory at some given time after the motion has passed away. That the judgment regarding motion by traversal occurs at a later time in the mind does not mean that it is merely a mental phenomenon.

Al-Rāzì's understanding of motion, which is a challenge to Avicenna's commitments, is grounded in these aforementioned discussions. The first aspect of Avicenna's understanding of motion on which he casts a critical eye is the idea that motion is not something that obtains all at once, but is gradual, since that which obtains all at once and is perfected in its totality has achieved a state of rest. As noted above, this interpretation of motion required also the adoption of the thesis that those things that are moving are partly actual and partly potential; for if they are entirely actual, they are at rest and if they are entirely potential, they do not exist. This proposition in turn led to the definition of motion as the first perfection of something in potentiality insofar as it is in potentiality vis-à-vis that total perfection. ${ }^{44}$ In other words, a challenge to this basic proposition that motion is a gradual emergence also stood to shake the entire edifice of Avicenna's theory. ${ }^{45} \mathrm{Al}-\mathrm{R} a \bar{z} \overline{\mathrm{l}}$ argues in the following fashion (and

43 Again, it is the persistence of motion that is figurative and motion is the sequential renewal of states, i.e., a traversal. Avicenna would say that motion is being in the middle and that, imagined as traversal, it does not exist extramentally.

${ }^{44}$ In arriving at this position, Avicenna is of course following the course of arguments presented in the tradition before him. The historical and philosophical details are examined in Hasnawi, "Définition," pp. 220ff., where the footnotes offer a rich set of references.

45 Al-Hilli notes a number of challenges to the elements of the theory Avicenna adopts. For example, against the idea of gradual change, he states that, in order to know the notion of "gradual", we must first know what it means to obtain at an instant (al-hușūl al-ān $\overline{)}$. And in order to know the latter, we must know what time is; and since the latter is the measure of motion, we must first know what motion is. So defining time in terms of the gradual is circular. (This is of course a challenge that was already noted by Avicenna.) Then he also points out that motion as a state of being between the beginning and end implies the notions "before" and "after", which, in turn, depend on time. So the circularity returns. In addition, as there is neither beginning nor end in celestial motions, the definition would not apply to them. Again, motion as a first perfection employs the notion of "first" which is another way of referring to what is before. This latter notion of "before" depends on the notion of time, which, in turn, depends on knowing what motion is. Finally, al-Hilli mentions that the 
like al-Baghdādī, he launches off with arguments we have already met in Avicenna):

Know that the important investigation at this juncture is the explanation of whether the gradual emergence of a single thing from potentiality to actuality can be intellected. For this is something agreed upon among the philosophers (hukamä), but I have a doubt about it. For one may say ( fa-li-q $\vec{a}$ ilin an yaqūla) that, when a thing changes, this change is either [1] due to the inherence of something in it or [2] due to the passing away of something from it. For if nothing of that which was non-existent is generated in it and nothing of that which was existent passes away from it, then it would be necessary for its state in that instant to be like the state before that instant. So there would be no change in it, though this had been supposed. This is absurd. So if a thing changes, then [there occurs] either the generation of a thing in it or the passing away of a thing from it. So let us suppose that something is generated in it. That which is generated had been non-existent and then it becomes existent. The existence of everything that is like this has a beginning and this beginning is indivisible. ${ }^{46}$ Otherwise, one of its parts is the beginning, [but] it, [i.e., the thing itself,] is not the beginning. So that which is generated either exists at the beginning of its existence or not. If not, then it is still in its non-existence, not existent at the beginning of its existence. If existence obtains for it, then either something of it persists (baqiya) in potentiality or it does not [so] persist. If it does not persist, then the thing has obtained in its totality ( $f \bar{\imath}$ tama amihi) at the first [moment] of its being generated. So it obtains all at once (duf'atan), not progressively. If something of it persists in potentiality, then that which persists is either exactly that which exists - and this is absurd, due to the impossibility of [the fact] that one [and the same] thing should be existent and non-existent all at once (dufatan wähidatan) - or [that which persists in potentiality] is something other than it. So then that which obtains first had obtained already in its totality and that which did not obtain is non-existent in its totality. So there is no one thing that obtains gradually. Rather there are things [that occur] successively. The gist is that it is impossible for a thing that has a singular ipseity ( $a l$-shay ${ }^{\prime}$ al-ahadī $a l$-dhāt) to obtain except all at once... The verification $(\operatorname{tah} q \bar{\imath} q)$ is that everything that is generated has been generated in its totality all at once and everything that is not generated is non-existent in its

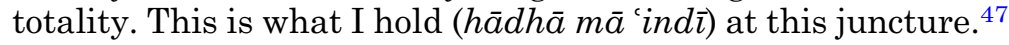

definition of motion as a state of being in the middle between the beginning and the end at a supposed ( $m a f r \bar{u} d$ ) middle terminus is inadequate because being-in-a-place relates to a mental posit, i.e., the terminus. As such, motion in the middle is also merely a mental posit and extramentally unreal. And if the termini obtain actually, then the being-in-place in relation to them would be divided into discrete units (la-kāna munqasiman ilā mā lā yanqasimu). In turn, the now-instant of its obtaining would be different from the now-instant of its departure and it would be at rest between the two events. See al-Hilli, al-Asrār, pp. 151ff.

46 See note 50 below.

47 Fakhr al-Dīn al-Rāzī, al-Mabāhith al-mashriqiyya fī ‘ilm al-țabīiyyāt wa-al-ilāhiyyāt, ed. Muhạmmad al-Baghdādī (Beirut, 1990), vol. 1, pp. 671-2. Al-Rāzī proceeds from this point to explain Avicenna's theory and then, rather surprisingly, to endorse it. He does not do so in his later work Sharh 'uyūn al-hikma. My inclination is to read this passage 
Al-Rāzī has taken issue with a central element in Avicenna's theory of motion, viz., the idea that a thing in motion in actuality is in potentiality with respect to the totality of its relevant perfection. To put it differently, he does not seem to draw a distinction, as Avicenna had done, between an accident like black, which must be black in the totality of its perfection with respect to itself, and motion, which is still potentially motion with respect to the totality of the perfection of that motion. This disagreement seems to be based on al-Rāzì's unwillingness to grant that any totality - whether a total body or a part, which in turn must be a totality in itself - can be analyzed in terms of actual change unless one first establishes its parameters. Once these parameters are established, then it is either only a part that can be said to have changed or a part, taken as a whole in itself, that is said to have done so. In the case of the latter, one comes full circle, since this new whole must be analyzed in terms of its parts. Taking up this same totality, if it does not exist at the moment of change, then it is non-existent and no change has in fact come about. If it does exist at the moment of change, then it has come to be all at once. Otherwise, if some of it is in potentiality, then only a part of the totality has come to be, while the rest is non-existent. ${ }^{48}$ The upshot is that all change occurs all at once and not gradually, producing the further consequence - one not explicitly articulated as such by al-Rāzì, but clearly hinted in the passage - that motion is not the first perfection of that which is in potentiality insofar as it is in potentiality. ${ }^{49}$

as an early indication of al-Rāzì's emergent position that culminates as a confident stance in the later work (see below). That this position should exist at a stage of his career when he was likely a supporter of Avicenna's position is still an intriguing fact that complicates al-Zarkān's chronology of al-Rāzī's intellectual development. See Muhammad al-Zarkān, Fakhr al-Dīn al-Rāzī wa-ārāùhu al-kalāmiyya wa-al-falsafiyya (Beirut, 1963), pp. 80ff. For further on al-Rāzì's engagement with Avicennism (and the historical recasting of his relationship with his philosophy), see Robert Wisnovsky, "Towards a genealogy of Avicennism," Oriens, 42.3-4 (2014): 323-63.

48 As an example, take a brown table that is five feet long; this table is to change its color to black gradually. Now if the parameters that are set are the entirety of the table, i.e., five feet, then in the next instant, either the table is entirely black or not, for it cannot be both brown and black (or if so, then the entirety of the five feet has changed to some other color between black and brown and this color is its new actuality, sans potentiality). Now if one states that only a part of the table - say three feet - has changed to black, then one cannot say that the table has changed to black, since the parameters were set at five feet. Alternatively, one might take the three changed feet as the subject of change. In such a case, three feet sets the new parameter and the entirety of the subject has changed. In either case, there is no gradual transformation of the table taken as a whole, once the parameters of what constitutes the whole have been determined.

49 Al-Rāzì's discussion appears also in the Mulakhkhas, Berlin Staatsbibliothek, MS Or. Oct. 629 , fol. $99^{\mathrm{r}}$, and, with the exception of the alternative theory presented in these texts, the ambit of both relates to Avicenna, The Healing, pp. 109ff. The position articulated here seems to be a variation on an atomist critique. More on this and on Rāzì's innovation will 
As noted above, following on the tradition he inherited, Avicenna had posited motion as a gradual change and had explicitly distinguished it from the category of change that occurs all at once, i.e., generation and corruption. ${ }^{50}$ In addition, the theory had to account for a state of being between two termini, something that an atomist theory could not satisfy (since it always required a division of the traversed body); and this state also could not be such as to be a total perfection in the manner of "black" and "square". These conditions, along with others mentioned above, contributed to the production of Avicenna's theory of motion as first perfection and, more importantly, of motion as a state of being in the middle. Al-Rāzì simply does not begin with Avicenna's assumption about the nature of motion as a gradual change. Rather, he establishes in his proof that there cannot in fact be any such motion at all, since the condition that allows for this possibility - i.e., being in the (dual) state of potentiality with respect to a total actuality - is absurd. In a related vein, he does not seem to subscribe to the idea of a state of being in the middle; for a thing either is or is not, in its totality, in a certain state, whether that state be the fact of being between two termini (change with respect to place) or of being a certain color (change with respect to quality). The consequence is that motion can only be all at once, with no further possibility of gradational divisibility. Finally, since he subscribes to this theory of motion, i.e., not of being in the middle, then he must be thinking of it, much like al-Mas'ūdì and al-Baghdādī, in terms of traversal.

Of course if al-Rāzì is thinking of motion as a collection of indivisible and sequential series of generations or corruptions that obtain in indivisible parts of time, then he can be charged with committing the

be presented below. I thank Bilal Ibrahim for sharing his digital copy of the Mulakhkhas with me.

${ }^{50}$ I should point out that in Book III, Chapter 6 of the Physics of the Shif $\vec{a}$, Avicenna argues that there is no first part of motion, but then he presents proofs that are very similar to those offered by al-Rāzī above (these passages most likely underlie al-Rāzì's theory). This may lead to some confusion, as Avicenna may appear to be stating that motion occurs all at once. He makes the point that, in motion by traversal, if one were to posit a first part or beginning of motion along a spatial magnitude and then to divide this spatial magnitude further (because of the possibility of infinite divisibility), then the first part of motion will also be divided, resulting in a first and second part. This new first part of motion will be a motion of a new whole. And so on. However, unlike al-Rāzì, Avicenna's concern is to show that, given these infinitely potential firsts, motion must be understood as change along infinitesimally smaller limits, so that there is no first part of motion. Given that al-Rāzì is not approaching the problem from the perspective of the infinite divisibility of a continuum, this same argument leads him to posit that change occurs to the totality of a thing all at once. In other words, Avicenna's thought experiment is grounded in the posit of an infinitely divisible spatial magnitude and body, whereas al-Rāzì's is grounded in the posit of a totality/whole. See Avicenna, The Healing, pp. 311ff, esp. 312-14. 
error of confusing motion with rest. ${ }^{51}$ For any actual and perfect obtaining without the residue of potentiality with respect to the totality of such an obtaining is tantamount to being at rest. This was one of the charges against the theory of motion that was forced upon the atomists so forcefully by Avicenna. Al-Rāzì, therefore, faces the dilemma of adopting an atomist scheme of motion, while deflecting the problem of conflating motion with rest. The solution he offers is conceptually interesting and seems to relate to some extent to the position of al-Baghdādī. In the Sharh 'uyūn al-ḥikma, al-Rāzī explains:

The fifth definition ( $\left.t a^{c} r \bar{i} f\right)$ of motion is what the later [philosophers] mentioned, viz., that [motion] is an expression [referring to] the first obtaining (husūl awwal) in a second locus (hayyiz)... [Motion with respect to the category of where] is called transfer (nuqla). Know that when a body obtains in a locus, its having obtained in that locus is not receptive of differentiation. This is so because either it obtains in it or it does not obtain in it. And there is no intermediacy (wassita) in between its obtaining in it. It is not said that when some of it leaves it and some of it persists (baqiya) in it, that is the intermediacy, because we say this [being in a locus] is an expression [pertaining] to the collection ( ajm $^{\prime} \bar{u}^{\epsilon} a$ ) [of the two parts]. So when some of it does not persist in that locus, the collection of that being-in-place does not persist in that place as it was. So it is established that there is no intermediacy between these two types [of being-in-place] at all. If this is established, it is necessary that the generation of this obtaining and the generation of the non-obtaining is all at once. It is not possible that this happen gradually at all. ${ }^{52}$

So far, al-Rāzī has reasserted his position from the Mabāhith, namely, that there can be no gradual coming to be. His argument is practically identical, but with the crucial addition of certain key terms that bring his target of criticism and his assumptions into sharp relief. The critique is directly leveled against Avicenna, as al-Rāzì is explicit in denying the state-between that is identified by Avicenna as motion. More precisely put, the state of being in the middle, i.e., between two termini, is considered impossible by al-Rāzī, since this implies that some of that which is in motion is in the original locus and some of it is in the next. However, the state of being

51 See al-Sayyid al-Sharīf al-Jurjānī, Sharh al-Mawāqif li-al-Qāộ̄ 'Adụd al-Dīn al-İjī wa-ma'ahu Hāshiyatā al-Siyālkūtī wa-al-Çelebī, ed. Mahmmūd al-Dimyāțī (Beirut, 1998), vol. 6, p. 209: "So motion is the opposite of rest in the first locus from which [the moving thing] transfers and [it is the opposite] of rest in the locus to which it transfers as well, as opposed to making it, i.e., motion, the being in the second locus. For if [motion] is made the very being in the second locus, it would be the opposite of being at rest in that from which it transfers and not of being at rest in that to which it transfers."

52 Fakhr al-Dīn al-Rāzì, Sharh 'uyūn al-ḥikma, ed. Aḥmad al-Saqqā (Cairo, n.d.), vol. 2, pp. 39-40. 
in a locus pertains to the totality/collection of the thing in motion, not to some part of it. The fact of obtaining in a locus is not receptive of differentiation: taken as a totality under consideration, either an object obtains or fails to obtain in its locus. ${ }^{53} \mathrm{Al}-\mathrm{Ra} z \bar{z}$ next explains:

If you know this, then we say that for as long as the body obtains in that locus, it is not in motion. When it comes to be non-obtaining in it, then the generation of this [fact of] non-obtaining only happens all at once. So in the instant which is the first of the instants of non-obtaining, it must already have obtained in the other locus (lā budda wa-an yakūna qad hasala fī hayyizin $\bar{a} k h a r a)$. Then the discourse about it, [i.e., the second locus,] is the same as for the first. Thus the gist of the discourse reduces to the [idea] that motion is an expression [referring] to sequential obtainings in serial loci (husūulāt muta'āqiba fī ahy $\bar{a} z$ mutalāhhiqa). ${ }^{54}$

Motion is described by al-Rāzī in terms of a sequentially obtaining series, very similar to the manner in which the earlier mutakallimūn viewed it. ${ }^{55}$ As such, motion is also understood as a traversal, not a state of being in the middle. And given that the existence of motion is something apprehended in a primary fashion, motion as traversal is taken to be extramentally real, though of course it does not all exist at the same time as a collected series. At the same time, al-Rāzì's theory of motion is a departure from that of the earlier mutakallimūn in that it deploys elements found in al-Mas'ùdì and, to a much greater extent, in al-Baghdādī. Drawing from the latter, especially, the crux of the discussion is placed in his understanding of motion as hușūlāt, which term must be understood in its precise verbal form as obtaining, i.e., as a process, not as existing in a stable mode. Motion is the fact of the first obtaining of something in a second locus, not of being in that locus, which is a state of rest.

Indeed a certain confusion over the meaning of hușul seems to have been registered in the literature. For an objection that al-Rāzì reports is that "the husūl of a body in the second locus is the end of the motion

53 A potential consequence of al-Rāzìss theory of motion is that it commits him to an atomist ontology, with its attendant dilemmas that were subject to the Avicennan attack. See below for details.

54 Al-Rāzī, Sharh 'uyūn, vol. 2, p. 41.

55 Compare, for example, the position of al-Ash'arī on this topic (Daniel Gimaret, La doctrine d'al-Ash'ari [Paris, 1990], pp. 109ff.) and especially of Abū al-Hudhayl, who appears to come rather close to al-Baghdādī and al-Rāzī: "Motions and rests are other than being in a place and touchings. The motion of a body from the first place to the second occurs in it while it is in the second place in the state of its being in it. It [i.e., motion] is its transfer (intiq $\bar{a} l$ ) from the first place and its departure from it. The rest of a body in the place is its tarrying in it for two moments (zamānayn)." Abū al-Ḥusayn al-Ash`arī, Maqālāt al-islāmiyyīn wa-ikhtilāf al-mușallīn, ed. Hellmut Ritter, 3rd edn (Wiesbaden, 1980), p. 355. 
and its point of [complete] traversal $\left(m a q t a^{c}\right)$. Motion, [however,] is the transfer (intiq $\bar{a} l$ ) from the first locus to the second locus." ${ }^{6} 6$ Al-Rāzi responds to this with the retort that there is no difference between obtaining and transfer except one that is the product of false estimation and imagination. To put it differently, the fact of obtaining is the fact of transfer.

This leaves of course one lingering issue, namely, that the obtaining must take place with respect to some specific locus; failing this fact, al-Rāzī will have to admit a state of being between two loci, something he denies repeatedly and explicitly. In other words, the adoption of a theory of the sequential and specific obtaining of motion with respect to specific and actual loci seems to run directly into a theory of atomism, along with its attendant challenges that were noted above. Now it is not entirely clear to me whether al-Rāzì is an atomist or thinking as an atomist at the time he penned the passage from the Sharh 'Uyūn al-hikma that is quoted above. It is, however, worth nothing that he himself raises the specter of atomism in this same passage in the form of a question:

If motion is an expression [referring] to these sequential obtainings (hușūlatt muta' $\bar{a} q i b a$ ) and each one of them is not receptive of division and if the matter is like this, then the body must be composed of parts/atoms $(a j z \vec{a})$, none of which is receptive of division. And this requires [the adoption of] the doctrine of the atom (al-qawl bi-al-jawhar al-fard). ${ }^{57}$

As a response to this question and as a statement of the position of the muhaqqiqūn, al-Razi writes that this point is correct and that there is no way to defend against this consequence. ${ }^{58}$

Now I think that it is worth pointing out that al-Rāzì's stance on the constitution of bodies and spatial magnitudes is actually irrelevant for his theory of motion. This is so because his proof depends merely on positing a totality and in claiming that change must be analyzed within the parameters of this delimited totality and that there is no middle

56 Ibid.

57 Al-Rāzì, Sharh, vol. 2, p. 41. See also a more elaborate explanation of this claim in $\overline{\mathrm{j}} \mathrm{j} \mathbf{1} /$ Jurjānī, Sharḥ al-Mawāqif, vol. 6, pp. 208-12.

58 Fa-hādhā al-kalāmu haqqun lā dāfic a 'anhu. Al-Rāzī, Sharh, vol. 2, p. 41. The Sharh 'uyūn is among the later works of al-Rāzì and, by the time he wrote it, it is highly likely that he had come to embrace the atomic theory of bodies. Thus this is very likely a welcome consequence. On the chronology of al-Rāzì's works, see Ayman Shihadeh, The Teleological Ethics of Fakhr al-Dīn al-Rāzi (Leiden, 2006), pp. 7ff. For further on al-Rāzì's later defense against atomism, see now Alnoor Dhanani, "The impact of Ibn Sīnā's critique of atomism on subsequent Kalām discussions of atomism," Arabic Sciences and Philosophy, 25 (2015): 79-104. On al-Rāzī's critique of atomism, see Carmela Baffioni, Atomismo e antiatomismo nel pensiero islamico (Napoli, 1982), pp. 211-75. On his defense of atomism, see Adi Setia, "Atomism versus hylomorphism in the kalam of Fakhr al-Din al-Razi: a preliminary survey of the Matalib al-'Aliyyah," Islam and Science, 4 (2006): 113-40. 
state between actuality and potentiality (as noted above). Thus let us imagine that this totality is a body composed of two atoms (1-2) and is extended over two loci (1a-2a), each with a magnitude of one atom. For one to say that this body as a whole has moved, all parts must depart from their first locus and arrive at a new one. Thus atom 1 must now be in locus $2 \mathrm{a}$ and atom 2 must be in locus $3 a$ (the locus immediately adjacent to 2a), so that the first obtaining in the new loci is what is defined as motion. (The same thought experiment can also be conducted with only one atom.) Alternatively, let us image a continuous body occupying a locus over a continuous magnitude. Again this body would be said to be in motion if all of its supposed parts depart from the original locus and arrive at a new one. In fact the only difference between the first and second cases of motion is that, in the former, there is no locus between loci $1 \mathrm{a}-2 \mathrm{a}-3 \mathrm{a}$, whereas, in the latter, there are infinitely many. Yet in principle the infinite divisibility of the continuum should still allow for one to argue that the totality of an object has moved to a new locus, without being forced into accepting a state of being in the middle. This is simply because the totality, insofar as it is a totality, is actually in the new locus. And this is all al-Rāzī seems to demand.59

59 The aforementioned argument aside, I strongly suspect that al-Rāzī and the tradition following him considered a theory of sequential obtainings as a concomitant of a theory of atomism. I have already adduced the passage from al-Rāzì's Sharh to highlight this point. Here is what al-Ijjī and al-Jurjānī have to say (the passage nicely highlights which theories of bodies and magnitudes were associated with which theory of motion): "Know that that upon which it is based, i.e., that upon which what he mentioned of motion in the sense of being in the middle and its extramental existence is based is the continuity of the loci in themselves and the non-existence of their discreteness into things that are indivisible absolutely (aslan), [which position] is based on the denial of the atom; we will speak about this and will give a full account of it. The [fuller account] is that, when the body [is taken] to be composed of atoms and when [it is taken] to move, there would not be a single motion and a single moving thing [in this case]. Rather there would be motions and moving things after [each of these] atoms. For the single moving thing is a single atom (fa-al-mutaharriku al-wāhidu huwa al-jawharu al-fardu al-wāhid). And when the spatial magnitude is composed of these atoms and we suppose that the single atom transfers from one atom to another conjoining atom, then motion by traversal has already obtained and there is no being-in-the-middle between the beginning and the end (wa-laysa hunāka tawassutun bayna al-mabda'i wa-al-muntahā). Rather there is only being in the first atom - and this is not motion by traversal - and being in the second atom - and this is motion, known as "the first being in the second locus" [this is precisely al-Rāzī's formulation]. As for the case when it is said that the atom and the composition of bodies from it are impossible, well then when the body transfers from one place to another, then there must be an extension (which is the spatial magnitude) between [these two places]. [This extension] is divisible from the aspect of the motion. Thus the first place is the beginning of this spatial magnitude and the second place is its end. And it is possible to suppose non-divided (ghayr munqasima) termini in it along the extension of the motion and the spatial magnitude be they points or lines or surfaces. [But] it is not possible to suppose them [to be] successive (mutatāliya). Otherwise the spatial magnitude would be composed of atoms either actually or potentially. And this is absurd. So the moving thing in it has a specific and individuated state in that which [lies] between the beginning and end [of the spatial magnitude] 


\section{CONCLUSIONS}

We have seen that the tradition preceding Avicenna had posited a number of challenges and conditions to which any viable theory of motion was required to respond. A theory of motion should have allowed for traversal across a middle between two termini. The only way to account for this requirement was to offer a refutation of atomism and to relegate motion by traversal to the status of a mental product. That the first of these two consequences should follow is obvious from the fact that traversing a middle necessitated the division of the atom. The second consequence was forced by the objection that motion should be a complete unity and extramental ipseity; since not all parts of the motion by traversal were actual at once, it was a mere mental notion. Yet another consideration was to distinguish motion from generation and corruption, i.e., to posit it as a gradual change. The sum of these concerns led Avicenna to innovatively develop the theory that motion is the actual extramental state of being in the middle over a continuum, a total first perfection of that which is in potentiality insofar as it is in potentiality (in virtue of the totality of that very perfection).

An early hint of disagreement with Avicenna appears in alMas 'ùdì's discussion of the causes of contingent entities. In the course of this discussion, he highlights a distinction between the cause of first generation and of the persistence of contingencies. In the case of the latter, al-Mas 'ùdī implicitly grants that motion by traversal is extramentally real, though its persistence is merely figurative. Though alMas'üdì's discussion is not focused on motion, it highlights two important aspects of its theories: first, the question of the extramental reality of motion by traversal was far from settled; and secondly, the question of traversal needed reexamination in light of the question of persistence, not existence.

Al-Mas' ūdī may well have drawn inspiration from the discussion found in al-Baghdādī, for whom motion by traversal is explicitly real and for whom there is indeed no persistence for motion. His argument is innovative: motion is to be understood as the fact of one thing touching another, of passing away from this state, and of touching yet another, in a sequential manner. All these events are extramentally real and they all present themselves to the mind serially. He is careful to stress that the fact that these events do not occur together does not

and its [reading nisbatuhu for nisbatuhā for sense] relation to these termini differs with respect to the supposed instants. Supposing [these instants] to be successive is also not possible; rather there is a time between each two supposed instants in which other instants may be supposed." (Īj̄̄/Jurjān̄̄, Sharh al-Mawāqif, vol. 6, pp. 209-10). 
mean that they cannot be considered together by the mind. Then their consideration together by the mind at a later stage - at an instant when they do not exist - does not imply in any way that they were not extramentally real. Since the constitutive elements of motion are all worthy of being called extramentally real, so is the traverse motion that is their collection. In this entire discussion, the crucial nuance to keep in mind is that, whereas for Avicenna, motion by traversal is the product of the mind's joining of two images - by the cooperation of the common sense and the image-bearing faculty with the external senses - for al-Baghdādī, the mind merely considers together the notions $\left(m a^{c} \bar{a} n \bar{\imath}\right)$ of the fact of touching, of existing in a state, of passing away from the state, etc. These notions are all extracted from the sensible experience of the extramentally real and are all available to the soul, which recalls them in relation to the faculty of memory. Motion by traversal is thus extramentally real and is unstable, incomplete, and non-unified and motion as being in the middle is, by implication, rejected as a theory.

Al-Rāzi, who builds upon elements of the theories of his two predecessors, takes a slightly different route to Avicenna. To begin with, he simply does not grant the idea that there can be such a thing as gradual change. His argument is based on his understanding that, in the consideration of the transformation of any subject, to say that some of it has changed and some not, is tantamount to granting that at least a part has completely changed. If it has not, then some part of that part must have changed. Whatever the case may be, this part or part of a part must itself constitute some kind of totality and, as a complete and actual totality, it has transformed all at once. In other words, he does not seem to draw a distinction between motion and other qualities. If then motion is the coming to be and passing away of wholes all at once, in what sense can one speak of change in the ordinary manner? AlRāzì's response is very similar to that of al-Baghdādì: motion is the first obtaining ( $h u s \bar{u} l)$ of a subject in a second locus; this fact of obtaining is identical to transfer (nuqla). In other words, motion is an extramentally real and sequentially repeating event, which is (presumably, in the case of al-Rāzì) imprinted in the mind as a set of notions for later consideration. As this first obtaining occurs in a specific locus, al-Rāzì faces the specter of atomism, which he seems gladly to embrace.

These early receptions of Avicenna's theory of motion had a major impact on their later deployments and readings. For example, alRāzì became the main lens through which Mullā Sadrā proposed adjustments to the historical understanding of Avicenna on motion; motion by traversal was accepted as extramentally real by the last text in traditional Physics of the late pre-modern period, the Hadiya sa ‘̇diyya of Khayrābādī, who also accepts the continuity of bodies; 
and these early defenses of motion by traversal seem to have posed some problems to later legal theorists in their elaboration of the theory of istisha $\bar{a} b$ (presumption of the continuity of a state and/or judgment). I shall elaborate on these points in a forthcoming publication. ${ }^{60}$

60 Khayrābādī, Hadīya, p. 93 (where he also accepts the reality of motion as being in the middle). Khayrābādī's psychology and epistemology also seem to be closely related to that of al-Baghdādī, an observation that was not made in an earlier publication (see Ahmed/ McGinnis, "Hadīya"). See Mullā Șadrā, al-Hikma al-mutáāliya fī al-asfār al-arba'a, ed. Maqșūd Muhammadī (Tehran, 1383 Sh.), vol. 3, pp. 29ff. In the context of legal theory (ușül al-fiqh), the reality of motion by traversal poses a problem for obligations that may be performed by choice within a range of time. For example, if the parts of time/motion, taken to be real, are, each of them, conditions for fulfilling an obligation completely and this obligation is legally designated as allowing a range of choices, then this obligation is both tightly specified with respect to the parts of time/motion and operative within a range of choices. To be specific, let us say that the period of obligatory prayer may be four hours and, as an obligation with a range of choices, a person may pray at any part of this range of time and fulfill the obligation. However, if each of the parts of the range of time condition the obligation as real parts, then the obligation also becomes specific to each of them and the choice of praying at any part of the range of time is no longer valid. The solution to this conundrum is that, in this problematic situation, one is taking motion and time in the sense of traversal, so that it has real parts. As such, to fulfill the entire obligation, one must fulfill the duty with respect to each of the parts. On the other hand, if one were to understand time/motion in the sense of being in the middle, then the obligation pertains to this motion/time as a continuum. In such a case, the relation of the supposed part to the continuum as a whole is that of the relation between a particular to a universal (not a relation of a part to a whole, as in motion by traversal). Thus the fulfillment of the duty with respect to any part satisfies the condition of fulfilling the duty with respect to the whole, just as the command "eat fruit" is fulfilled by eating an apple (not so if by "fruit" we mean all individual instances of fruit). See, for example, Muhammad Gharawī, Buḥūth fī al-ușūl, Daftar-i Intishārāt-i Islāmī (1416 AH), pp. 68-9. 